\title{
Robert Gallo forced off NIH stage after HHS vetoes public briefing
}

Washington. The US National Institutes of Health (NIH) were last week told to cancel a public meeting featuring Robert $\mathrm{C}$. Gallo after officials of the Department of Health and Human Services (HHS) decided that such a meeting would be political suicide.

Observers say that HHS was concerned that an airing of the controversy surrounding Gallo's conduct of research over the past decade would disrupt delicate negotiations with the French government to resolve the question of royalty rights stemming from a blood test for the AIDS virus developed by Gallo and Luc Montagnier of the Pasteur Institute in Paris. Congressional pressure to delay the release of the report of a completed investigation into alleged misconduct by Gallo that has found him innocent of fraud but guilty of uncollegial behaviour may also have influenced the government.

On 23 June, Howard Temin, who shares a Nobel prize for the discovery of reverse transcriptase, received the US National Medal of Science from President George Bush in a ceremony in the White House Rose Garden. Less than two hours later, as chairman of the National Cancer Advisory Board's AIDS subcommittee, he received another, less welcome message from the government in the form of a hand-delivered letter from the general counsel of HHS, warning him to cancel the meeting.

Temin, outraged by the order, decided to hold the meeting just long enough to announce his feelings in public. "The forced cancellation does not give me a good feeling about the upper reaches of government", he says.

The offending letter was written by HHS counsel Michael Astrue. "This letter is to reiterate my oral advice to you, which is that the meeting you have scheduled for tomorrow to review matters relating to allegations of misconduct against Dr Robert Gallo exceeds the statutory authority of your committee and therefore must be canceled", Astrue wrote. "You need to be aware that the unauthorized expenditure of federal funds may expose you and others to various types of liability."

Temin admits to feeling threatened by Astrue's letter. "If I hadn't felt threatened I wouldn't have cancelled the meeting", he says. One week later, Temin says he still has no clear idea why the meeting was illegal and what liability he was exposed to. Furthermore, he calls Astrue's timing (less than 24 hours before the meeting) "insulting and rude".

Astrue says he was just applying the law. The cancer advisory board, which has oversight over the National Cancer Institute and which is appointed by the White House, "has no authority to conduct misconduct investigations", he says. Temin's response is that "this would not have been a misconduct investigation. We were very careful about that."

Temin says the meeting was intended to "draw lessons" from the controversy, to ask questions about Gallo's management of his laboratory and to consider not fraud but

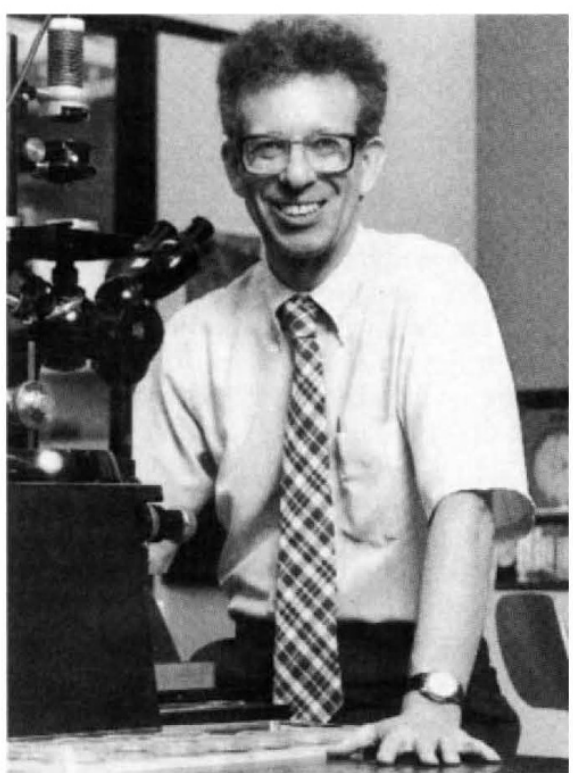

Howard Temin is outraged by the government's "rude" behaviour.

what he calls "sharp practices" in science issues not of data but of collegiality and rudeness. "A society like the United States, with its savings and loan scandals and dirty politics, may not be one to expect that scientists and science should have no sharp practices."

Days before declaring the advisory board meeting illegal, Astrue also objected to it on policy grounds, saying that to allow Gallo to defend himself at a government meeting would "look as if the government had made up its mind in an ongoing decision process, when it hasn't". According to NIH sources, Astrue said that the meeting would be "purple Kool-Aid for the department", an apparent reference to the suicides by Kool-Aid of cult followers of Jim Jones in Guyana several years ago.

But Bernadine Healy, the NIH director who fought bitterly with Astrue in a failed attempt to salvage the meeting, does not accept that explanation. She says that HHS has "fundamentally criminalized a meeting of the National Cancer Advisory Board". Healy recently reviewed and accepted a controversial report (two years in the making) from the NIH's now defunct Office of Scientific Integrity (OSI) that found Gallo innocent of fraud or serious misconduct in the AIDS virus affair (see Nature 357, 3; 1992). Healy's decision to accept the OSI's findings was powerfully influenced by the judgement of a committee of the NIH's scientific directors (many of whom openly dislike Gallo), who independently reviewed the report and concluded that the evidence is in his favour. To their own surprise, she says, "they agreed that he deserves the credit for developing the blood test".

Healy believes that Gallo, who has been the subject of numerous derogatory news articles and television shows, has been wronged and that the NIH has a duty to make things right. That is what lay behind her wish to hold the meeting. Healy, like members of the cancer board, wanted Gallo to have a chance to speak on the record, with the blessing of the NIH.

But it was not to be. Speculation about the reasons include the role of two other players who took an off-stage part in this melodrama.

New York attorneys for the Pasteur Institute, which is conducting secret negotiations with HHS for a larger share of the AIDS blood test royalties it now shares with the United States, sternly objected to the Gallo meeting and urged HHS to call it off because they saw it as a "press conference". Rebuffed at first, they then scheduled (and subsequently cancelled) a press conference of their own to follow the NIH meeting.

Then there is the question of the OSI report, still awaiting the signature of Healy's boss, James Mason, the HHS assistant secretary for health. For now, Mason has been effectively silenced by US Representative John Dingell (Democrat, Michigan), whose oversight committee has authority to review allegations of fraud. Dingell's staff recently sent Mason a 45-page rebuttal of the OSI report. Both documents have been leaked to the press.

The gist of Dingell's document is that the OSI report is faulty because of questions it allegedly failed to ask and conclusions it did not draw. This leaves Mason with a dilemma. He can support Healy's judgement and risk being called to explain himself before Dingell; he can order what would amount to a new study; or he can stall.

The latest word is that there will be no word for a couple of months at least, during which the melodrama will no doubt continue in the press.

Barbara J. Culliton 